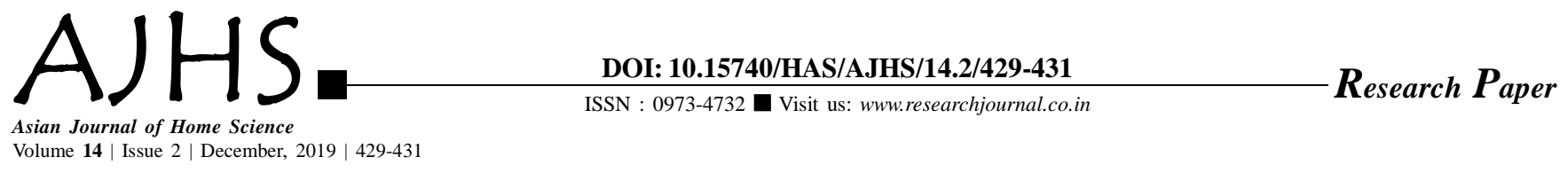

\title{
The effects on temperament of twins in Khadar zone
}

\author{
Reetu Devi and Bimla Dhanda
}

Received: 23.09.2019; Revised: 08.11.2019; Accepted: 22.11.2019

See end of the paper for authors' affiliations

\section{Reetu Devi}

Department of Human Development and Family

Studies, C.C.S. Haryana

Agricultural University, Hisar

(Haryana) India

Email : reetubhadu54@gmail.

com
ABSTRACT : Family income is generally considered a primary measure of a nation's financial prosperity. Temperament refers to our inborn personality traits, which are genetic in nature. The present study was conducted in four districts namely; Hisar, Fatehabad, Rohtak and Jind of Haryana state with the purpose of availability of maximum numbers of twins in the required age group. A sample of 296 pairs of twins in the age group for the study. Temperament was taken as dependent variable and family income was taken as independent variable. The Malhotra Temperament Schedule (MTS) developed by Malhotra and Malhotra (1988) was used to assess child's temperament. This schedule can be used on all child populations whether normal or abnormal, within an age range of 4-10 years of both sexes and of any socio-economic class. Malhotra Temperament Schedule consists of nine dimensions or variables of child's temperament and the operational terms of these dimensions are given as: Activity, Rhythmicity Approach or withdrawal, Adaptability, Threshold of responsiveness, Intensity of reaction, Quality of mood, Distractibility, Attention span and persistence. These nine dimensions were further grouped into five categories namely sociability, emotionality, energy, attentivity/distractibility and rhythmicity. To arrive at factor scores the means of the constituting temperament dimension are to be added. The Malhotra Temperament Schedule (MTS) schedule measured temperament variables on a 5 point rating scale, and categorized by standardized method. Result revealed that family income was non-significantly associated with sociability $\left(\chi^{2}=4.29\right)$, emotionality $\left(\chi^{2}=1.02\right)$, energy $\left(\chi^{2}=4.94\right)$, distractibility $\left(\chi^{2}=4.50\right)$, rhythmicity $\left(\chi^{2}=1.30\right)$ and total temperament $\left(\chi^{2}=5.68\right)$.

KEY WORDS: Temperament, Family income, Personality traits, Twins, Behaviour, Children, Emotions, Development

- HOW TO CITE THIS PAPER : Devi, Reetu and Dhanda, Bimla (2019). The effects on temperament of twins in Khadar zone. Asian J. Home Sci., 14 (2) : 429-431, DOI: 10.15740/HAS/AJHS/14.2/429-431. Copyright@ 2019: Hind Agri-Horticultural Society. 